\title{
HUBUNGAN PENGUASAAN MATERI THAHARAH DENGAN KESADARAN MENJAGA KEBERSIHAN SEBAGAI ACUAN MANAJEMEN LINGKUNGAN SEKOLAH
}

\author{
Achmad Ali Fikri \\ IAIN Kudus, Kudus, Indonesia \\ Fikri@stainkudus.ac.id \\ M. Farid Bustomi \\ IAIN Kudus, Kudus, Indonesia \\ Mfaridbustomi@gmail.com \\ Astitik Nikmah \\ IAIN Kudus, Kudus, Indonesia \\ Astitik.nikmah1201@gmail.com
}

\begin{abstract}
Abstrak
Penelitian ini bertujuan untuk mengetahui penguasaan materi thaharah siswa, kesadaran menjaga kebersihan dan hubungan penguasaan materi thaharah siswa dengan kesadaran menjaga kebersihan sebagai acuan manajemen lingkungan sekolah. Populasinya ini adalah 125 siswa kelas VII MTs Hasan Kafrawi Jepara dan sampel 70 siswa dengan random sampling. Menggunakan pendekatan kuantitatif dengan teknik pengumpulan data tes, kuesioner, dan observasi. Kemudaian menggunakan analisis deskripsi dan analisis korelasi. Hasil penelitian menunjukkan nilai $r$ hitung $=0,431$ berarti $r$ hitung $>r$ tabel $(0,431>0,235)$ Hal ini menunjukkan bahwa terdapat hubungan positif dan signifikan antara penguasaan materi thaharah siswa dengan kesadaran menjaga kebersihan. Hal ini dapat dijadikan acuan manajemen lingkungan di MTs Hasan Kafrawi Jepara.
\end{abstract}

Kata Kunci: Penguasaan materi thaharah, kesadaran menjaga kebersihan, manajemen lingkungan sekolah.

\begin{abstract}
This study aims to determine the mastery of student subject matter, the awareness of maintaining cleanliness of the school environment, and the relationship of mastery of student subject matter with the awareness of maintaining hygiene as a reference for school environment management. The population was 125 students of class VII MTs Hasan Kafrawi Jepara and a sample of 70 students with random sampling. Using a quantitative approach to the technique of collecting test data, questionnaires, and observations. Then using description analysis and correlation analysis. The results showed the value of $r$ arithmetic $=0.431$ means $r$ arithmetic $>r$ table $(0.431>0.235)$ This shows that there is a positive and significant relationship between mastery of student subject matter with awareness of maintaining cleanliness. This can be used as a reference for environmental management in MTs Hasan Kafrawi Jepara.
\end{abstract}

Keywords: Mastery of thaharah material, awareness of maintaining cleanliness, school environment management. 


\section{A. Pendahuluan}

Dalam berbagai aktifitas sangat diperlukan adanya manajemen, termasuk manajemen lingkungan di suatu sekolah. Hal tersebut agar semua kegiatan dapat berjalan dengan baik sesuai tujuan dan target bersama. Dalam mencapai sebuah tujuan tersebut ada kalanya terdapat banyak masalah, cara dan langkah yang harus dilalui sehingga semuanya dapat tercapai secara maksimal. Pastinya hal tersebut membutuhkan proses dan tidak instan (fikri, 2018).

Dalam kegiatan pengelolaan diperlukan data yang valid sebagai acuan, yaitu sebelum mendesain manajemennya itu sendiri. Baru kemudian dilanjutkan dengan perencanaan, action dan evaluasi. Hanya saja selama ini dalam kebanyakan kegiatan pengelolaan atau manajerial hal tersebut kurang diperhatikan. Dalam kegiatan manajerial kebanyakan langsung pada perencanaan dan langkah-langkah selanjutnya. Hal tersebut mengapa penelitian ini dirasa sangat urgen untuk dilakukan sebelum melakukan kegiatan manajerial untuk lingkungan sekolah. Selain itu dengan penelitian ini dapat mengetahui berbagai permasalahan yang ada yang dapat dijadikan rujukan dan acuan untuk langkah selanjutnya.

Masalah kehidupan selalu muncul seiring dengan berputarnya waktu dan perkembangan zaman. Berbagai masalah muncul dari berbagai sudut kehidupan, salah satu masalah yang terjadi yaitu menyangkut masalah kebersihan yang menjadi masalah penting dalam kehidupan (Ahsin W. Alhafidz, 2007: 60). Agama Islam sangat menjunjung tinggi kebersihan yaitu diatur dalam masalah thaharah. Thaharah (bersuci) di dalam Islam sebenarnya menerangkan secara jelas tentang ruang lingkup sampai hikmah Islam mewajibkan menjaga kebersihan. Pembahasan thaharah dalam literatur fiqih Islam selalu mengawali pembahasan sebelum yang lainnya. Hal demikian menunjukkan betapa penting dan besarnya perhatian Islam terhadap masalah kebersihan. Karena itu, bersuci termasuk ibadah pokok yang diwajibkan mengingat besarnya nilai kebersihan di dalamnya. Pentingnya thaharah dalam Islam ini sesuai dengan firman Allah yaitu QS. Al-Baqarah: 222

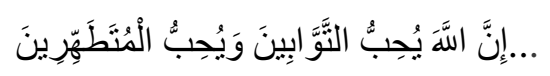

"Sesungguhnya Allah menyukai orang-orang yang bertaubat dan menyukai orangorang yang mensucikan diri” (Kementerian Agama RI, 2011: 35). 
Dari ayat tersebut dijelaskan bahwa Allah SWT sangat menyukai semua orang yang membersihkan diri dari segala kotoran dan menjauhkan diri dari segala kemungkaran, orang seperti itu lebih disukai oleh Allah.

Selain dari ayat tersebut, disebutkan juga di dalam hadits bahwasannya kebersihan adalah sebagian dari iman. Sehingga kebersihan adalah sebab yang mendasar untuk meraih suatu pahala dalam beribadah. Jadi, jika semua yang kita gunakan itu bersih maka akan memunculkan pikiran-pikiran yang positif.

Fiqih merupakan sistem norma (aturan) yang mengatur hubungan manusia dengan Allah, sesama manusia maupun lingkungan hidup. Aspek fiqih menekankan pada kemampuan cara melaksanakan ibadah dan muamalah yang benar dan baik. pembekalan materi yang baik dalam lingkup sekolah akan membentuk pribadi yang mandiri, bertanggungjawab, dan berakhlak karimah. Sehingga memudahkan peserta didik mengaplikasikannya dalam kehidupan sehari-hari.

Salah satu dari tujuan pembelajaran fiqih adalah membentuk peserta didik mempunyai pengetahuan, sikap, dan perilaku mampu menjaga keseimbangan, keserasian, keharmonisan hubungan manusia dengan tuhan dan manusia dengan alam semesta. Tujuan tersebut merupakan faktor penting terciptanya kehidupan yang bahagia dan damai di muka bumi.

Munculnya masalah lingkungan hidup pada hakikatnya dimulai dari interaksi manusia dengan alam. Bila terjadi ketidakseimbangan hubungan antara manusia dengan lingkungan disitulah terjadi permasalahan. Permasalahan manusia dalam teori lingkungan dikatakan bahwa manusia terkadang bersikap baik terhadap lingkungan terkadang sebaliknya. Sehingga terjadi kerusakan lingkungan dan sumber daya alam (Rahmat K dan Dwi Susilo, 2008: 16).

Kebersihan lingkungan sekolah, dibutuhkan kerjasama antar siswa, guru, dan semua warga madrasah. Siswa adalah salah satu pendukung kebersihan madrasah, karena jumlah siswa sangat banyak jika dibandingkan dengan warga madrasah yang lain. Siswa yang memiliki IQ dan EQ tinggi pasti memiliki kecerdasan dan kecekatan dalam berfikir. Maka jika diingatkan untuk tidak membuang sampah sembarangan ataupun mencoret-coret bangku serta menjaga lingkungan madrasah, siswa akan mematuhi hal tersebut. 
Mengingat bahwa pelajaran fiqih merupakan pelajaran yang paling dasar dalam pelaksanaan beribadah, diharapkan siswa mampu meningkatkan budi pekerti siswa untuk lebih cinta terhadap lingkungannya. Perhatian atau tidaknya siswa terhadap lingkungan itu tidak terlepas dari seorang guru yang mengajar tentang kebersihan (thaharah) dikelas. Jika dari siswanya sendiri sudah kurang sadar akan kebersihan lingkungan maka penguasaan materi fiqihnya harus dipertanyakan. Meskipun begitu, siswa yang sudah menguasai materi kebersihan belum tentu ia bisa mengaplikasikannya terhadap lingkungan sekitar. Karena pada dasarnya kebiasaan itu terjadi dari aktivitas dilakukan secara berulang-ulang. Maka dari itu, demi membangun karakter siswa yang peduli akan kebersihan lingkungan, seorang guru harus mempunyai kompetensi dalam bidang fiqih serta selalu menjadi suri tauladan bagi siswa dalam menjaga kebersihan lingkungan.

Dengan diajarkan materi kebersihan (thaharah) di sekolah sangat membantu bagi lingkungan sekolah. Hal ini harus bersamaan dengan kebiasaan-kebiasaan yang dicontohkan oleh pihak instansi sekolah, seperti pembuangan sampah pada tempatnya dan mensucikan najis sesuai syari'at islam. Tugas siswa adalah memperdalam ilmu di bidang thaharah serta mengamalkannya untuk lingkungan sekolah agar tercipta suasana yang nyaman dan sehat.

Penelitian ini membahas tentang penguasaan materi thaharah yang dimilik oleh siswa dengan kesadaran menjaga kebersihan lingkungan sekolah pada siswa kelas VII MTs Hasan Kafrawi Mayong Jepara. Penelitian ini bertujuan untuk mengetahui penguasaan materi thaharah siswa, kesadaran siswa dalam menjaga kebersihan lingkungan sekolah, dan hubungan penguasaan materi thaharah siswa dengan kesadaran menjaga kebersihan lingkungan sekolah. Pada akhirnya hasilnya dapat dijadikan acuan manajemen lingkungan MTs Hasan Kafrawi Mayong Jepara.

Penelitian ini adalah penelitian kuantitatif yaitu suatu proses menemukan pengetahuan yang menggunakan data berupa angka sebagai alat untuk menemukan keterangan mengenai apa yang diketahui (Masrukhin, 2018: 1). Dalam penelitian ini melalui cara perhitungan statistik yang menggunakan rumus product moment dan analisis korelasi menggunakan program SPSS 21.

Populasi merupakan keseluruhan dari obyek penelitian (Suharsimi Arikunto, 2010: 27). Populasi dalam penelitian ini adalah kelas VII MTs Hasan Kafrawi 
Mayong Jepara yaitu sebanyak 125 siswa yang terdiri dari kelas VII A, VII B, dan VII C. Sampel adalah bagian dari jumlah dan karakteristik yang dimiliki oleh populasi (Sugiyono: 2007: 62). Sampel dalam penelitian ini adalah 70 siswa dengan teknik pengambilan sampel menggunakan random sampling, yaitu pengambilan sampel dilakukan secara acak tanpa memperhatikan strata yang ada dalam populasi dan populasi dianggap homogen (Sugiyono, 2007: 64). Dalam pengambilan sampel ini berpedoman bahwa apabila subjek kurang dari 100, lebih baik diambil semua sehingga penelitian adalah penelitian populasi. Tetapi jika jumlah subjeknya besar (lebih dari 100), maka dapat diambil $15 \%$ atau $25 \%$ atau lebih, tergantung setidaktidaknya dari kemampuan peneliti dilihat dari waktu, tenaga dan dana, sempit luasnya lahan wilayah pengamatan dari setiap subyek karena hal ini menyangkut banyak sedikitnya dana, dan besar kecilnya resiko yang di tanggung oleh peneliti. Untuk penelitian yang resikonya besar, tentu saja jika sampelnya besar hasilnya lebih baik (Sunarto, 1987: 134).

Dalam penelitian ini terdapat dua variabel yaitu independent dan dependent. Variabel independent atau sering disebut variabel bebas adalah variabel yang mempengaruhi variabel dependent (variabel terikat) dan variabel dependent atau sering disebut variabel terikat adalah variabel yang dipengaruhi atau yang menjadi akibat karena adanya variabel bebas (Sugiyono, 2009: 61). Variabel bebas dalam penelitian ini adalah penguasaan materi thaharah yang dimiliki oleh siswa dan variabel terikat dalam penelitian ini adalah kesadaran menjaga kebersihan lingkungan sekolah.

Teknik pengumpulan data dalam penilitian ini menggunakan tes, kuesioner dan observasi. Tes adalah suatu alat atau prosedur yang sistematis dan objektif untuk memperoleh data-data atau keterangan-keterangan yang diinginkan tentang seseorang dengan cara yang boleh dikatakan tepat dan cepat (Anas Sudijono, 1998: 151). Tes ini digunakan untuk mendapatkan data tentang tingkat penguasaan materi thaharah siswa kelas VII MTs Hasan Kafrawi Mayong Jepara. Kuesioner merupakan teknik pengumpulan data yang dilakukan dengan cara memberi seperangkat pertanyaan atau pernyataan tertulis kepada responden untuk dijawabnya (Masri Singarimbun, 1995: 175). Kuesioner ini digunakan untuk mengetahui seberapa besar kesadaran menjaga kebersihan lingkungan sekolah yang 
dimiliki oleh siswa kelas VII MTs Hasan Kafrawi Mayong Jepara. Observasi merupakan teknik pengumpulan data yang berkenaan dengan perilaku manusia, proses kerja gejala-gejala alam, dan bila responden yang diamati tidak terlalu besar (Sugiyono, 2009: 203). Observasi digunakan untuk mengadakan pengamatan secara langsung terhadap keadaan MTs Hasan Kafrawi Mayong Jepara.

Analisis data dalam penelitian ini menggunakan analisis deskripsi dan analisis korelasi. Analisis deskripsi yaitu mendeskripsikan skor pada masingmasing variabel dengan mencari mean, standar deviasi dan pengkategorian kelas interval. Analisis korelasi yaitu untuk mengetahui hubungan penguasaan materi thaharah siswa dengan kesadaran menjaga kebersihan lingkungan sekolah pada siswa kelas VII MTs Hasan Kafrawi Mayong dengan menggunakan rumus korelasi product moment dan analisis korelasi menggunakan program SPSS 21.

Hipotesis dalam penelitian ini adalah:

H1: Terdapat hubungan posistif antara penguasaan materi thaharah siswa dengan kesadaran menjaga kebersihan lingkungan sekolah pada siswa kelas VII MTs Hasan Kafrawi Mayong Jepara.

H0: Tidak terdapat hubungan posistif antara penguasaan materi thaharah siswa dengan kesadaran menjaga kebersihan lingkungan sekolah pada siswa kelas VII MTs Hasan Kafrawi Mayong Jepara.

Dalam penelitian ini hipotesis yang diajukan adalah terdapat hubungan positif antara penguasaan materi thaharah siswa dengan kesadaran menjaga kebersihan lingkungan sekolah pada siswa kelas VII MTs Hasan Kafrawi Mayong Jepara.

\section{B. Pembahasan}

Pembahasan di sini tentang data hasil penelitian dan hasil analisis data tentang tingkat penguasaan materi thaharah siswa dan tingkat kesadaran menjaga kebersihan lingkungan sekolah yang dimiliki oleh siswa. Data ini bersumber dari hasil tes dan kuesioner yang telah diisi sebelumnya oleh siswa. Kemudian data diangkakan dengan penilaian dan penskoran yang telah ditentukan. Pembahasan disini meliputi hasil analisis penguasaan materi thaharah siswa, hasil analisis tingkat kesadaran menjaga kebersihan lingkungan siswa, hasil analisis korelasi, 
hasil analisis uji signifikan korelasi, hasil pengujian hipotesis, dan pembahasan hasil penelitian.

\section{Hasil Analisis Penguasaan Materi Thaharah Siswa}

Data penguasaan materi thaharah siswa didapat dari tes yang dilakukan kepada siswa yang kemudian digabung, dirata-rata, dan diklasifikasikan. Tes menggunakan soal sebanyak 10 item dan pengisiannya di isi secara langsung oleh setiap siswa. Untuk mendapatkan nilai kuantitatif tingkat penguasaan materi thaharah yang dimiliki oleh siswa, penilaian dilakukan dengan cara dikalikan 10 untuk jawaban yang benar sehingga jika jawaban yang diberikan oleh siswa benar semua nilai maksimalnya adalah 100. Berdasarkan hasil tes yang dilakukan kepada siswa kelas VII MTs Hasan Kafrawi Mayong Jepara bisa dilihat pada tabel di bawah ini:

\section{Tabel 1. Hasil Tes Penguasaan Materi Thaharah Siswa}

\begin{tabular}{ccc}
\hline No & Nilai & Frekuensi \\
\hline $\mathbf{1}$ & 30 & 6 \\
$\mathbf{2}$ & 40 & 11 \\
$\mathbf{3}$ & 50 & 21 \\
$\mathbf{4}$ & 60 & 17 \\
$\mathbf{5}$ & 70 & 12 \\
$\mathbf{6}$ & 80 & 1 \\
$\mathbf{7}$ & 90 & 2 \\
& Jumlah & 70 \\
\hline
\end{tabular}

Berdasarkan nilai di atas maka hasil perhitungan mean atau rata-rata yang diperoleh adalah 57,06 dan untuk pengkategorian nilai ini berdasarkan hasil dari konversi nilai dengan standar skala lima. Perhitungan konversi nilai dengan standar skala lima berdasarkan rumus:

$\mathrm{M}+(1,5 \mathrm{SD})$

$\mathrm{M}+(0,5 \mathrm{SD})$

$\mathrm{M}-(0,5 \mathrm{SD})$

$\mathrm{M}-(1,5 \mathrm{SD})$

M - (1,5 SD) kebawah (M. Iqbal Hasan, 2005: 34-35).

Berdasarkan rumus diatas sebelum menentukan konversi nilai maka harus menentukan standar deviasi, standar deviasi diperoleh dari rumus:

$s=\frac{\sqrt{\sum F i(X i-M e)^{2}}}{(n-1)}($ Masrukhin, 2018: 97) 
Sehingga, dari perhitungan berdasarkan rumus di atas standar deviasi yang diperoleh adalah 11,252. Maka, hasil perhitungan konversi nilai dengan standar skala lima bisa dilihat dibawah ini:

Tabel 2. Interval Nilai dan Kualifikasi Tingkat Penguasaan Materi Thaharah Siswa

\begin{tabular}{ll}
\hline Interval Nilai & Kategori \\
\hline $\mathbf{7 4 - 1 0 0}$ & Sangat Baik \\
$\mathbf{6 3}-\mathbf{7 4}$ & Baik \\
$\mathbf{5 2}-\mathbf{6 3}$ & Cukup \\
$\mathbf{4 1}-\mathbf{5 1}$ & Kurang \\
$\mathbf{< 4 1}$ & Sangat Kurang \\
\hline
\end{tabular}

Berdasarkan hasil rata-rata nilai siswa dalam tes penguasaan materi thaharah adalah 57,06, nilai ini menunjukkan bahwa rata-rata yang dihasilkan dalam kategori cukup yang artinya siswa cukup menguasai materi thaharah.

\section{Hasil Analisis Kesadaran Menjaga Kebersihan Lingkungan}

Data kesadaran menjaga kebersihan lingkungan madrasah didapat dari hasil jawaban kuesioner yang diberikan peneliti kepada siswa yang kemudian digabung dan dirata-rata. Dalam kuesioner yang diberikan oleh peneliti menggunakan 10 item dan pengisiannya di isi secara langsung oleh setiap siswa. Alternataif jawaban dalam kuesioner adalah sangat sesuai, sesuai, tidak sesuai, dan sangat tidak sesuai. Untuk mendapatkan nilai kuantitatif tingkat kesadaran menjaga kebersihan lingkungan madrasah yang dimiliki oleh siswa, penilaian dilakukan dengan cara memberikan nilai 4 untuk jawaban sangat sesuai, nilai 3 untuk jawaban sesuai, nilai 2 untuk jawaban tidak sesuai, dan nilai 1 untuk jawaban sangat tidak sesuai. Sehingga, nilai maksimal yang didapat siswa adalah 40. Berdasarkan hasil tes yang dilakukan kepada siswa kelas VII MTs Hasan Kafrawi Mayong Jepara bisa dilihat pada tabel dibawah ini: 
Tabel 3. Hasil Tes Kesadaran Menjaga Kebersihan Lingkungan Sekolah Siswa

\begin{tabular}{ccc}
\hline No & Nilai & Frekuensi \\
\hline $\mathbf{1}$ & 26 & 3 \\
$\mathbf{2}$ & 27 & 5 \\
$\mathbf{3}$ & 28 & 3 \\
$\mathbf{4}$ & 29 & 4 \\
$\mathbf{5}$ & 30 & 13 \\
$\mathbf{6}$ & 31 & 15 \\
$\mathbf{7}$ & 32 & 15 \\
$\mathbf{8}$ & 33 & 7 \\
$\mathbf{9}$ & 34 & 3 \\
$\mathbf{1 0}$ & 35 & 2 \\
& Jumlah & 70 \\
\hline
\end{tabular}

Dari hasil nilai kuesioner diatas rata-rata yang diperoleh adalah 30,76 dan untuk pengkategorian nilai ini berdasarkan hasil dari konversi nilai dengan standar skala lima. Perhitungan konversi nilai dengan standar skala lima berdasarkan rumus:

$\mathrm{M}+(1,5 \mathrm{SD})$

$\mathrm{M}+(0,5 \mathrm{SD})$

$\mathrm{M}-(0,5 \mathrm{SD})$

$\mathrm{M}-(1,5 \mathrm{SD})$

M - (1,5 SD) kebawah (M. Iqbal Hasan, 2005: 34-35).

Berdasarkan rumus diatas sebelum menentukan konversi nilai maka harus menentukan standar deviasi, standar deviasi diperoleh dari rumus:

$s=\frac{\sqrt{\sum F i(X i-M e)^{2}}}{(n-1)}($ Masrukhin, 2018: 97)

Sehingga, dari perhitungan berdasarkan rumus diatas standar deviasi yang diperoleh adalah:

Tabel 4. Interval Nilai dan Kualifikasi Tingkat Kesadaran Menjaga Kebersihan Lingkungan Sekolah Siswa

\begin{tabular}{cc}
\hline Interval Nilai & Kategori \\
\hline $\mathbf{3 4}-\mathbf{4 0}$ & Sangat Baik \\
$\mathbf{3 2}-\mathbf{3 3}$ & Baik \\
$\mathbf{3 0}-\mathbf{3 1}$ & Cukup \\
$\mathbf{2 8}-\mathbf{2 9}$ & Kurang \\
$<\mathbf{2 8}$ & Sangat Kurang \\
\hline
\end{tabular}


Berdasarkan hasil nilai rata-rata yang diperoleh siswa yaitu 30,76 maka kesadaran menjaga kebersihan lingkungan yang dimilik siswa masuk dalam kategori cukup.

\section{Hasil Analisis Korelasi}

Berdasarkan hasil analisis yang diperoleh menggunakan rumus korelasi product moment dan analisis korelasi dengan program SPSS 21 menunjukkan bahwa korelasi antara prediktor $\mathrm{X}$ (penguasaan materi thaharah siswa) dengan kriterium Y (kesadaran menjaga kebersihan lingkungan sekolah) menghasilkan indeks korelasi sebesar 0,431, bisa dilihat pada perhitungan dibawah ini:

$$
\begin{aligned}
r_{x y} & =\frac{N \sum X Y-\left(\sum X\right)\left(\sum Y\right)}{\sqrt{\left\{N \sum X^{2}-\left(\sum X\right)^{2}\right\}\left\{N \sum Y^{2}-\left(\sum Y\right)^{2}\right\}}} \text { (Masrukhin, 2018: 195) } \\
& =\frac{70 \times 117320-(3790 \times 2151)}{\sqrt{\left\{70 x 218100-(3790)^{2}\right\}\left\{70 \times 66405-(2151)^{2}\right\}}} \\
& =\frac{8212400-8152290}{\sqrt{\{15267000-14364100\}\{4648350-4626801\}}} \\
& =\frac{60110}{\sqrt{\{902900\}\{21549\}}} \\
& =\frac{60110}{\sqrt{19456592100}} \\
& =\frac{60110}{1394869} \\
& =0,4309=0,431
\end{aligned}
$$

Untuk analisis korelasi dengan program SPSS 21 menunjukkan bahwa korelasi antara prediktor X (penguasaan materi thaharah siswa) dengan kriterium Y (kesadaran menjaga kebersihan lingkungan sekolah) menghasilkan indeks korelasi sebesar 0,431, bisa dilihat pada tabel dibawah ini: 
Tabel 5. Analisis Korelasi Penguasaan Materi Thaharah Siswa dengan Kesadaran Menjaga Kebersihan Lingkungan Sekolah

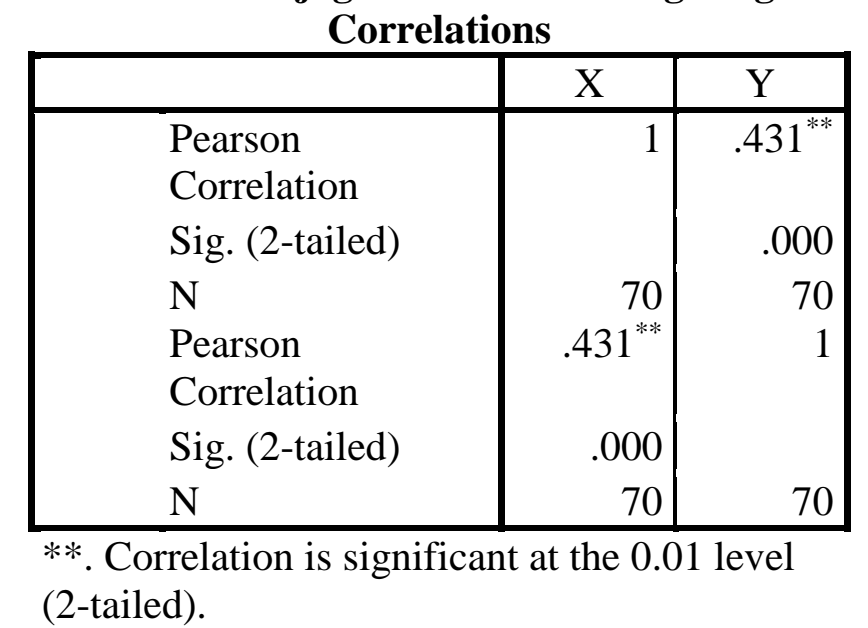

Berdasarkan hasil di atas untuk memberian penafsiran terhadap hasil koefisien korelasi yang ditemukan dapat dilihat pada tabel dibawah:

Tabel 6. Pedoman Interpretasi Terhadap Koefisien Korelasi (Sugiyono, 2007: 231)

\begin{tabular}{cc}
\hline Interval Koefisien & Tingkat Hubungan \\
\hline $\mathbf{0 , 0 0}-\mathbf{0 , 1 9 9}$ & Sangat Rendah \\
$\mathbf{0 , 2 0}-\mathbf{0 , 3 9 9}$ & Rendah \\
$\mathbf{0 , 4 0}-\mathbf{0 , 5 9 9}$ & Sedang \\
$\mathbf{0 , 6 0}-\mathbf{0 , 7 9 9}$ & Kuat \\
$\mathbf{0 , 8 0}-\mathbf{1 , 0 0 0}$ & Sangat Kuat \\
\hline
\end{tabular}

Berdasarkan uji korelasi antara penguasaan materi thaharah siswa dengan kesadaran menjaga kebersihan lingkungan sekolah pada kelas VII MTs Hasan Kafrawi Mayong Jepara diperoleh indeks korelasi 0,431 yaitu berada dalam kategori sedang atau cukup.

\section{Hasil Analisis Uji Signifikan Korelasi}

Untuk mengetahui korelasi antara penguasaan materi thaharah siswa dengan kesadaran menjaga kebersihan lingkungan sekolah pada siswa kelas VII MTs Hasan Kafrawi Mayong Jepara signifikan atau tidak, bisa dilihat dari hasil uji korelasi atau $r$ hitung yang dibandingkan dengan $r$ tabel pada $\mathrm{N}=70$ signifikansi $5 \%$ maupun $1 \%$. Hasil $\mathrm{r}$ hitung $=0,431$ sedangkan $\mathrm{r}$ tabel signifikansi $5 \%=0,235$ maka $r$ hitung $>r$ tabel $(0,431>0,235)$. Hasil $r$ hitung 0,431 sedangkan $\mathrm{r}$ tabel signikansi $1 \%=0,306$ maka $\mathrm{r}$ hitung $>\mathrm{r}$ tabel 
$(0,431>0,306)$. Berdasarkan hasil tersebut maka korelasi antara penguasaan materi thaharah dengan kesadaran menjaga kebersihan lingkungan adalah signifikan, karena $\mathrm{r}$ hitung lebih besar dari $\mathrm{r}$ tabel pada signifikansi 5\% maupun $1 \%$.

\section{Hasil Pengujian Hipotesis}

Hipotesis yang diambil dalam penelitian ini adalah terdapat hubungan positif antara penguasaan materi thaharah siswa dengan kesadaran menjaga kebersihan lingkungan sekolah pada siswa kelas VII MTs Hasan Kafrawi Mayong Jepara. Untuk menguji hipotesis tersebut diterima atau ditolak dapat dilihat pada hasil perhitungan korelasi yaitu $\mathrm{r}$ hitung $=0,431$, karena $\mathrm{r}$ hitung $=0,431>\mathrm{r}$ tabel signifikansi $5 \%=0,235$ dan $\mathrm{r}$ hitung $=0,431>\mathrm{r}$ tabel signifikansi $1 \%=0,306$. Berarti apabila penguasaan materi thaharah siswa tinggi maka kesadaran menjaga kebersihan lingkungan sekolah yang dimiliki oleh siswa juga tinggi dan begitu pula sebaliknya apabila penguasaan materi thaharah siswa rendah maka kesadaran menjaga kebersihan lingkungan sekolah yang dimiliki oleh siswa juga rendah dengan ini maka hipotesis yang diajukan diterima.

\section{Pembahasan Hasil Penelitian}

Penelitian ini membahas mengenai hubungan penguasaan materi thaharah siswa dengan kesadaran menjaga kebersihan lingkungan sekolah yang dimiliki oleh siswa kelas VII MTs Hasan Kafrawi Mayong Jepara. Berdasarkan hasil penelitian dari 70 siswa nilai rata-rata untuk penguasaan materi thaharah siswa adalah 57,06 yang masuk dalam kategori cukup dan nilai rata-rata untuk kesadaran menjaga kebersihan lingkungan madrasah yang dimiliki oleh siswa adalah 30,76 masuk dalam kategori cukup.

Berdasarkan analisis antara prediktor X (penguasaan materi thaharah siswa) dengan kriterium Y (kesadaran menjaga kebersihan lingkungan sekolah) menghasilkan indeks korelasi sebesar 0,431. Angka tersebut menunjukkan bahwa korelasi antara penguasaan materi thaharah siswa dengan kesadaran menjaga kebersihan lingkungan madrasah yang dimiliki oleh siswa kelas VII MTs Hasan Kafrawi Mayong Jepara dalam kategori sedang atau cukup. Hasil indeks korelasi atau $r$ hitung $=0,431$ sedangkan $r$ 
hitung signifikansi 5\%=0,235 maka $\mathrm{r}$ hitung $>\mathrm{r}$ tabel $(0,431>0,235)$. Hasil $\mathrm{r}$ hitung 0,431 sedangkan $\mathrm{r}$ tabel signikansi 1\%=0,306 maka $\mathrm{r}$ hitung $>\mathrm{r}$ tabel $(0,431>0,306)$. Berdasarkan hasil tersebut maka korelasi antara penguasaan materi thaharah dengan kesadaran menjaga kebersihan lingkungan signifikan.

Berdasarkan hasil penelitian maka hipotesis yang diajukan diterima yang berarti adanya hubungan yang positif dan signifikan antara penguasaan materi thaharah siswa dengan kesadaran menjaga kebersihan lingkungan sekolah pada siswa kelas VII MTs Hasan Kafrawi. Jadi apabila penguasaan materi thaharah siswa tinggi maka kesadaran menjaga kebersihan lingkungan sekolah yang dimiliki oleh siswa juga tinggi dan begitu pula sebaliknya apabila penguasaan materi thaharah siswa rendah maka kesadaran menjaga kebersihan lingkungan sekolah yang dimiliki oleh siswa juga rendah.

\section{Simpulan}

Berdasarkan analisis data dan pembahasan tentang hubungan penguasaan materi thaharah dengan kesadaran menjaga kebersihan lingkungan siswa kelas VII MTs Hasan Kafrawi Mayong Jepara, dapat ditarik kesimpulan sebagai berikut:

1. Tingkat penguasaan materi thaharah siswa kelas VII MTs Hasan Kafrawi Mayong Jepara masuk dalam kategori cukup. Hal ini dapat dilihat dari hasil nilai mean atau rata-rata 57,06 terdapat pada interval (52-63) dan hasil nilai tersebut termasuk dalam kategori cukup dan artinya kemampuan siswa dalam menguasai materi thaharah cukup atau bisa dikatakan siswa cukup menguasai materi thaharah.

2. Tingkat kesadaran menjaga kebersihan lingkungan madrasah yang dimiliki oleh siswa kelas VII MTs Hasan Kafrawi Mayong Jepara masuk dalam kategori cukup. Hal ini dapat dilihat dari hasil mean atau rata-rata yaitu 30,76 masuk dalam interval $(30-31)$ dan hasil nilai tersebut termasuk dalam kategori cukup dan dari hasil tersebut artinya siswa dalam memiliki kesadaran menjaga kebersihan lingkungan madrasah cukup atau bisa dikatakan siswa memiliki kesadaran menjaga kebersihan lingkungan madrasah. 
3. Berdasarkan hasil dari penelitian yang di interpretasikan dengan korelasi product moment dan dengan program SPSS 21 menunjukkan bahwa nilai $\mathrm{r}$ hitung adalah 0,431 . Hasil penelitian ini adalah $r$ hitung $>r$ tabel yang berarti pada taraf signifikansi $5 \%=0,235$ maka $\mathrm{r}$ hitung $>\mathrm{r}$ tabel $(0,431>0,235)$. Sedangkan $\mathrm{r}$ tabel pada taraf signifikansi $1 \%=0,306$ maka $\mathrm{r}$ hitung $>\mathrm{r}$ tabel $(0,431>0,306)$. Hal ini menunjukkan bahwa $\mathrm{H} 1$ diterima dan menunjukkan terdapat hubungan yang positif dan signifikan antara penguasaan materi thaharah dengan kesadaran menjaga kebersihan lingkungan siswa kelas VII MTs Hasan Kafrawi Mayong Jepara. Sehingga dapat disimpulkan bahwa semakin tinggi penguasaan materi thaharah siswa maka kesadaran menjaga kebersihan lingkungan madrasah yang dimiliki oleh siswa juga tinggi dan begitu pula sebaliknya apabila penguasaan materi thaharah siswa rendah maka kesadaran menjaga kebersihan lingkungan madrasah yang dimiliki oleh siswa juga rendah.

Setelah mengetahui hubungan antara penguasaan materi thaharah dengan kesadaran menjaga kebersihan maka selanjutnya pihak sekolah dapat menetukan langkah selanjutnya terkait manajemen lingkungan MTs Hasan Kafrawi Mayong Jepara. Sehingga apa yang direncanakan dan dilaksanakan memiliki acuan data yang valid. 


\section{Daftar Pustaka}

Alhafidz, Ahsin W. 2007. Fikih Kesehatan. Jakarta: AMZAH.

Arikunto, Suharsimi. 2010. Prosedur Penelitian Suatu Pendekatan Praktik. Jakarta: Rineka Cipta.

Fikri, Achmad Ali dan Ahmad Sauqil Jazil. 2018. Manajemen Fasilitas Terhadap Progresivitas Siswa. Jurnal Quality, Vol. 6, No. 2: 14-23.

Hasan, M. Iqbal. 2005. Pokok-pokok Materi Statistik I: Statistik Deskriptif. Jakarta: Bumi Aksara.

K, Rahmat dan Dwi Susilo. 2008. Sosiologi Lingkungan. Jarakta: Raja Grafindo.

Kementerian Agama RI. 2011. At-Thayyib: Al-Qur'an Transliterasi Per Kata dan Terjemah Per Kata. Jawa Barat: Cipta Bagus Segara.

Masrukhin. 2018. Statitik Deskriptif dan Inferensial. Kudus: Media Ilmu Press.

Singarimbun, Masri. 1995. Metode Untuk Survei. Jakarta: Pustaka.

Sudijono, Anas. 1998. Pengantar Evaluasi Pendidikan. Jakarta: PT Raja Grafindo Persada.

Sugiyono. 2007. Statistika Untuk Penelitian. Bandung: Alfabeta.

Sugiyono. 2009. Metode Penelitian Kuantitatif, kualitatif, dan R\&D. Bandung: Alfabeta.

Sunarto. 1987. Teknik Sampling. Jakarta: Proyek Lembaga Pendidikan Tenaga Kependidikan Departemen Pendidikan dan Kebudayaan. 